\title{
Twenty years of conversion: from Scots pine plantations to oak dominated multifunctional forests
}

\author{
Tomáš Vrška ${ }^{(1-3)}$, \\ Jaroslav Ponikelský (2), \\ Petra Pavlicová(3), \\ David Janík ${ }^{(1)}$, \\ Dušan Adam ${ }^{(1)}$
}

\begin{abstract}
A conversion of previously even-aged pine-dominated forests to uneven-aged and multi-functional oak-dominated forests has been ongoing since 1993 in the Pyramida experimental forest (95 ha) situated in the buffer zone of Podyji National Park, Czech Republic. Based on repeated surveys in 1992, 2003 and 2013, the conversion was assessed according to changes in: (i) the proportion of species; (ii) the distribution of DBH; (iii) the distribution of patches; and (iv) the distribution of forest types. The proportion of conifers decreased from $61.0 \%$ to $42.0 \%$, and the proportion of broadleaved species increased accordingly. A sharp decline in the number of trees in the DBH class 70-109 mm was caused by the intense release of understorey broadleaved trees in young Scots pine small pole stage stands. The number of large habitat trees steadily increased in the DBH classes $430+\mathrm{mm}$. The mean size of one patch decreased from 0.8 ha $(1992)$ to 0.4 ha (2013). The spatial proportion of the target forest type (uneven-aged oak-dominated forest) increased from $8.5 \%$ in 1992 to $45.0 \%$ in 2013 , and $35.1 \%$ of the area was fully converted during the 20 years. We expect $69.1 \%$ of the area to be converted after 30 years (2023).
\end{abstract}

Keywords: Scots Pine, Conversion, Oak Dominated Forest, Uneven-aged Silviculture, National Park

duction functions of forests. The originally easily understood and clearly targeted concept of uneven-aged forestry has served as a basis for expanding and defining purpose-modified concepts of forestry and silviculture, including "nature-based" (Johann 2006, Diaci et al. 2011), "close-tonature" (Schütz 1999), "ecological” (Seymour \& Hunter 1999), and "multiaged" (O'Hara 2014).

These broader concepts were in reaction to a diversified demand that had two distinct directions: (i) production management, which had, however, more support for fulfilling non-production functions (Diaci et al. 2011, O'Hara 2014) and (ii) the restoration management of forests located mainly in protected areas, primarily focused on the restoration or maintenance of specific functions and forest structure. These latter forests are more suitable for $\square$ (1) Department of Forest Ecology, Silva Tarouca Research Institute, Lidická 25/27, Brno, 60200 (Czech Republic); (2) Podyjí National Park Administration, Na Vyhlídce 5, Znojmo, 669 02 (Czech Republic); (3) Department of Silviculture, Mendel University in Brno, Faculty of Forestry and Wood Technology, Zemědělská 3, Brno, 61300 (Czech Republic)

@ Tomáš Vrška (tomas.vrska@vukoz.cz)

Received: Dec 29, 2015 - Accepted: Aug 10, 2016

Citation: Vrška T, Ponikelský J, Pavlicová P, Janík D, Adam D (2016). Twenty years of conversion: from Scots pine plantations to oak dominated multifunctional forests. iForest 10: 75-82. - doi: 10.3832/ifor1967-009 [online 2016-10-19]

Communicated by: Andrea Cutini the protection of threatened species and as niches of biodiversity in the scale of landscape mosaics (Carey 2003, Decocq et al. 2004, Göttmark 2007), where timber production is a possible but secondary product, and not considered necessary. While the first direction is defined more generally and has broader use, the second is almost always variously applied according to purposes defined by nature conservation requirements (Göttmark 2013). Both directions have a common ground, however, i.e., to abandon a uniformity embodied especially by age-evenness and to create a forest environment with heterogenic spatial and species diversity.

An important tool in changing a forest structure from even-aged to uneven-aged is conversion (Schütz 2001, 2002a). The principles of conversion have been broadly used for the even-aged Norway spruce monocultures in Europe (Sterba 2002), with the aim to create mixed forests but where spruce still has an important position in the species mix and spatial vegetation structure. The conversion of pine-dominated even-aged forests is less common, and has mainly been performed in Germany (Zerbe 2002), even though the concept of Dauerwald was founded on its basis (Möller 1922). Unlike Norway spruce monocultures, the conversion of pine-dominated even-aged forests is more often associated with complete changes in tree species composition. Silvicultural strategies for the conversion of young and ageing Scots pine stands have been defined according to expected regeneration and the time of con- 
version (Kint et al. 2006), and simulations of conversion have been tested (Kint et al. 2009). However, results verifying these principles in practice have not yet been published, and this is the main goal of our paper.

Between 1992 and 1993, the principles of forest management in both the core and buffer zones of Podyjí National Park (Czech Republic) were defined in terms of goals for each zone (Škorpík 1993). For the buffer zone (where our study is located) the main principles were:

- to protect the core zone from external influences (invasive species, agriculture, etc.);

- to protect the surroundings of the national park from disturbances in the core zone;

- to protect and increase biodiversity using management to promote naturalness, which creates stands with heterogeneous spatial structure, and using older methods of forest management (e.g., coppicing, coppice with standards), higher amounts of deadwood, etc.;

- to provide a steady source of timber for the local communities located in prevailing agricultural land.

According to these main principles, the conversion of pine-dominated even-aged forests in the buffer zone of a national park, such as at Podyjí National Park, must respect the conservation objectives and the variability of management types (sensu Göttmark 2013). Such a conversion represents a more fundamental change in the state of the forest than does conversion in an economic forest, with priorities focused rather on: (i) an irregular spatial diversity (sensu Schütz 2002a); (ii) autochthonous species diversity; (iii) higher deadwood diversity and amount; and (iv) efforts for an economically profitable system (e.g., firewood for local people).

The original state of forests in Podyji National Park was evaluated and recorded before conversion, allowing for future assessments of the efficiency and appropriateness of crucial decisions. Here, twenty years after the beginning of conversions, we ask the following fundamental questions:

- what changes have taken place over twenty years in the species composition and diameter at breast height (hereinafter DBH) structure?

- how have the qualitative parameters (spatial structure, forest types distribution) of the forest changed?

- how long will the conversion take?

\section{Material and methods}

\section{History}

The area of the Podyjí National Park (hereinafter PNP) is among the longest settled areas in Central Europe, being continuously inhabited since 5-6000 BC (Čižmář 2008). The forest history in the PNP has been described by Škorpík (1993), Vrška (1998), and Reiterová \& Škorpík (2012). For this study, changes in the proportion of European beech (Fagus sylvatica) are particularly important, since this used to be one of the main original forest tree species. However, it was predominantly used for the production of charcoal, and its proportion gradually declined to a level of only several percent, surviving to the present only in the form of large over-matured trees.

During the Cold War period (1948-1989), the territory of today's national park was intersected by the so-called "iron curtain" (built in 1951). The area of actual buffer zone of PNP was managed by the standard procedures of socialist forest manage-

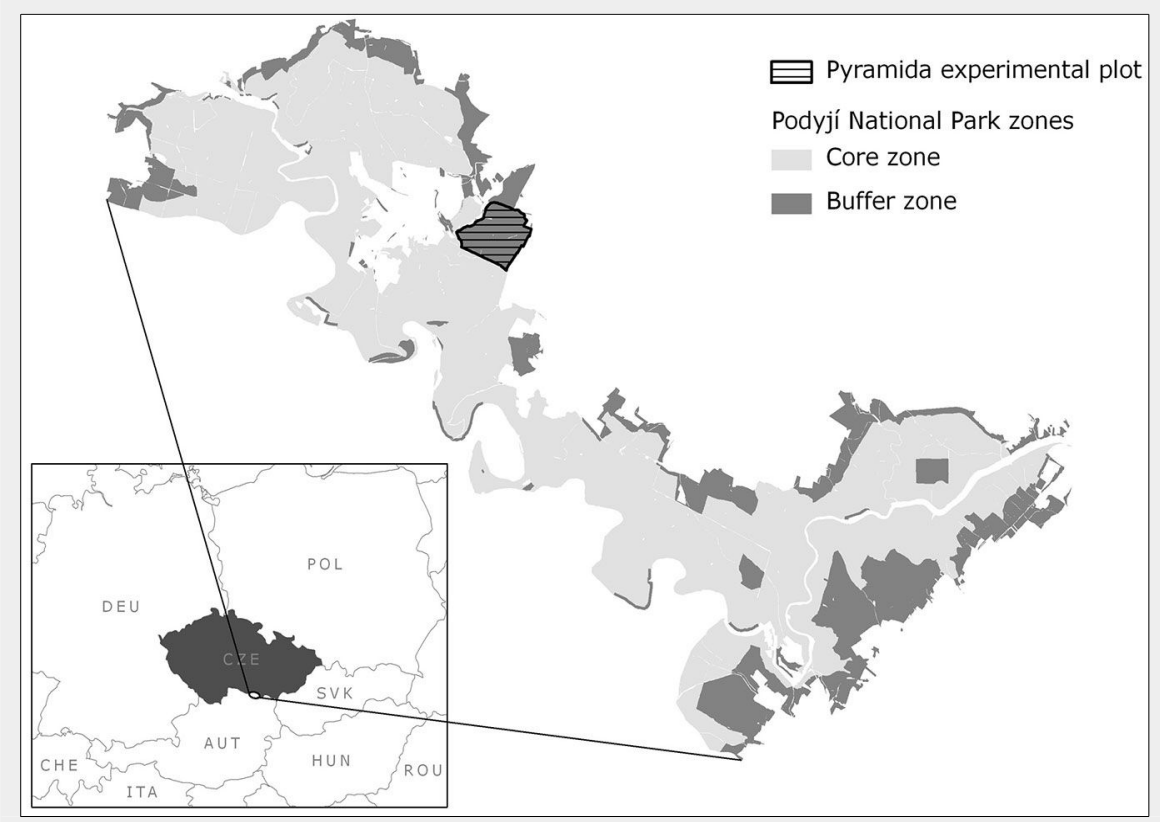

Fig. 1 - Location of the Pyramida study site. ment. That primarily meant the gradual removal of ancient oak and hornbeam coppices and their replacement by plantations of Scots pine (Pinus sylvestris) monocultures. This process fortunately failed to be completed. This resulted in a mosaic with the remnants of mixed broadleaved forests and Scots pine monocultures where hardwoods regenerated in the understorey thanks to the dispersal of seeds from old trees, as well as shoots growing from stumps and old stools. After the fall of the iron curtain during the "Velvet Revolution" (1989), many border restrictions were lifted and the PNP was established in 1991.

\section{Conversion principles}

Based on the definition of the functions of the buffer zone (see Introduction), conversion guidelines were developed for the conversion of Scots pine dominated forests. These stands covered approximately 900 ha of forest in the buffer zone of the national park. Our study is focused on the forest Pyramida (Fig. 1), which has been used as an experimental area since 1992 and represents a complex range of all forest types under the conversion process. Basic indicators (tree species composition, DBH distribution, patch dynamics, forest types changes) were surveyed in 1992, 2003, and 2013 (DBH distribution in 2003 and 2013 only), and analyzed. These indicators were used to verify the accuracy of silvicultural practices, assess forest management planning in the PNP, and to derive the rate of conversion.

The basic principles of conversion were as follows:

- terminate clear-cut logging and stop the artificial regeneration of Scots pine (1992);

- maximize the potential for broadleaves trees in Scots pine stands, avoiding the creation of new homogenous stands by planting on clear-cut areas;

- spatially divide large areas of former even-aged stands;

- artificially introduce beech, which, with some exceptions (rare over-matured trees) were not capable of natural restoration and spreading, in the form of understorey or small scale gaps (0.01$0.06 \mathrm{ha}$ );

- gradually move to the group selection silvicultural system modified for light-demanding tree species with the help of DBH differentiation and spatial differentiation;

- during thinning, primarily prefer oak (Quercus sp.) with a mixture of hornbeam (Carpinus betulus), small-leaved linden (Tilia cordata), European beech ( $F$. sylvatica) and other broadleaved species.

Study site

Average yearly temperature in the PNP is between 8 and $9{ }^{\circ} \mathrm{C}$, average precipitation is $550-600 \mathrm{~mm}$, with $65.0 \%$ occurring during the vegetation period (Tolasz 2007). In a biogeographical sense, the PNP lies in the 


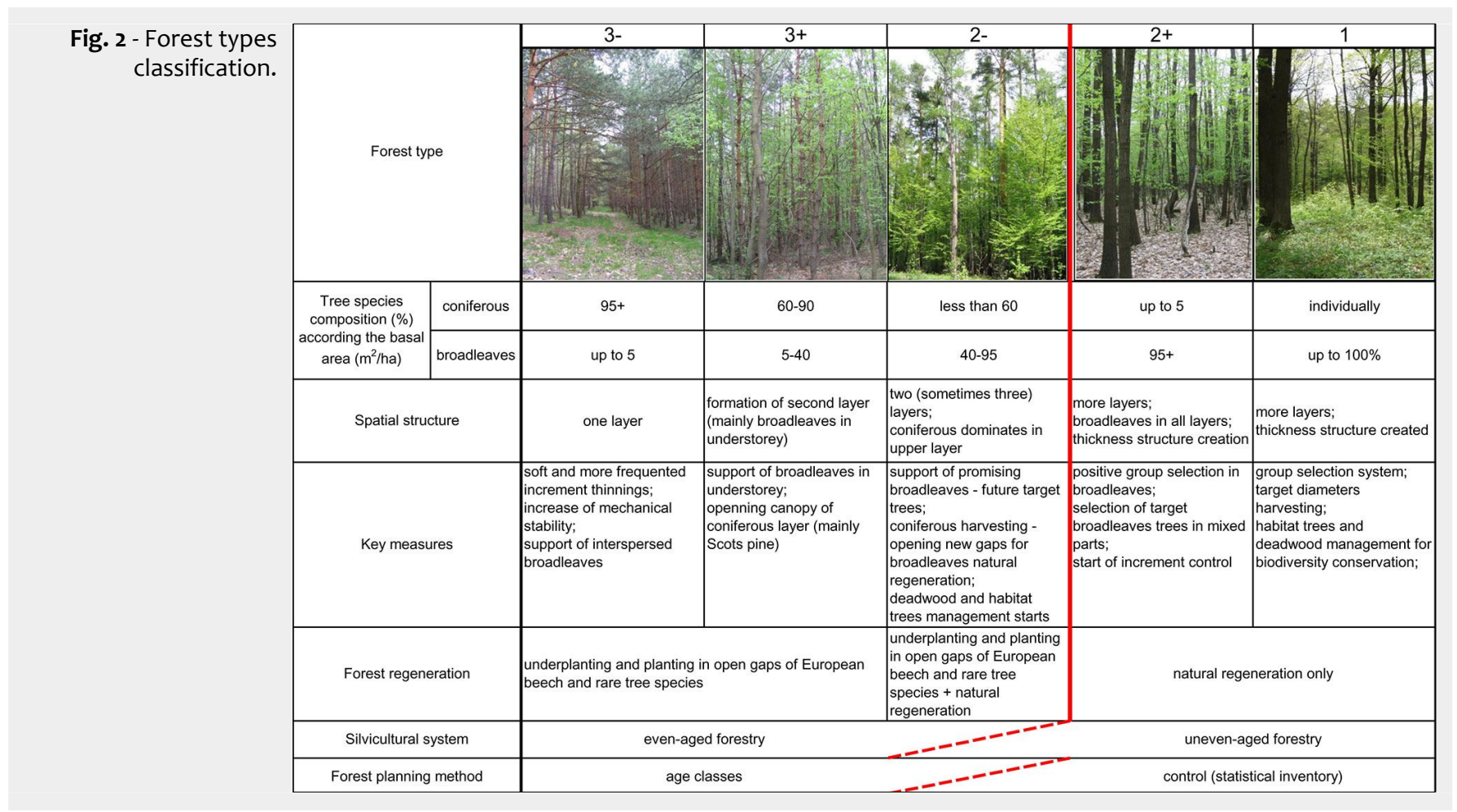

transition zone between the Hercynian and Pannonian provinces (mesophytic and thermophytic), which together with the varied morphology of the river valley and plateau creates high species diversity (Chytry \& Vicherek 1995).

The Pyramida study site covers 95.1 ha (Fig. 1) on the plateau and north-, westand south-oriented moderate slopes, with an elevation ranging between 380 and 435 $\mathrm{m}$ a.s.l. The geological bedrock consists mainly of gneiss, mica schist and similar rocks of Proteozoic to Paleozoic age (Škorpík 1993). Soils are classified into the cambisol and luvisol units (IUSS Working Group 2014).

\section{Tree species composition and DBH distribution changes}

A forest management plan (hereinafter FMP) for the PNP created for the period 1992-2001 (Anonymous 1992) served as a primary source of data for the first stage of assessment. This FMP was prepared by the method of age classes, because at that time even-aged forest stands dominated. Because of how the FMP was created, it was not possible to assess the DBH distribution at the study site, and therefore only the proportion of tree species in the entire Pyramida forest has been assessed since 1992.

In 1993 and 2013, statistical inventories that were part of inventories for the whole national park were conducted in Pyramida. Due to the smaller area of the monitored site ( $95.1 \mathrm{ha})$ and the wood storey structure, the inventory of the Pyramida forest used a plot spacing network of $170 \times 175 \mathrm{~m}$, as opposed to the $250 \times 250 \mathrm{~m}$ network used for the whole territory of the PNP. Each inventory plot consisted of a circle with a radius of $12.62 \mathrm{~m}\left(500 \mathrm{~m}^{2}\right)$ that was further divided into 4 concentric circles. All measured parameters are given in the Supplementary material (Tab. S1, Tab. S2, Tab. S3). Assessments of the inventory survey, including the calculation of confidence intervals ( $95 \%, \alpha=0.05)$, were performed in Field-Map Inventory Analyst ${ }^{\circledR}$ software (http://www.fieldmap.cz). To compare the changes in tree species composition in $1992 / 2003 / 2013$ the mean values of confidence intervals (from inventories in 2003 and 2013) were used. Species names follow Kubát (2002).

\section{Patch dynamics (texture changes)}

Patch dynamics includes the formation of a multi-aged and heterogeneous spatial forest structure (in combination with forest type changes), represented by the gradual fragmentation of formerly large, homogenous and usually even-aged forests. This should result in an optimization of patchiness for the group selection of light-demanding tree species, where the size of one patch is up to about 0.2 ha. In 1992, 2003 and 2013, texture patches were analyzed primarily in ortho-rectified aerial photographs and located onto maps in the scale 1:5000. These maps were used for the validation and specification of boundaries of all patches in the field. Each patch represents a clearly defined and field-detected area occurring in a certain growth stage of the forest, differing from surrounding stands and exposed to the same type of silvicultural measure. Spatiotemporal data and analyses were carried out in the software $\operatorname{ArcGIS}^{\circledast}$ (ESRI, Redland, CA, USA), R (R Development Core Team 2011) and MS Excel $^{\circledR}$.

\section{Forest types changes and duration of} conversion

To assess the conversion process, a fivedegree scale of forest types (FT) was developed, characterizing the entire qualitative range of existing stands in 1992 from younger, even-aged Scots pine monocultures to multi-aged heterogeneous oak dominated mixed forests (Fig. 2). The parametrization of individual FTs was performed such that applicability for practical forestry was retained, as well as to maximize clarity for foresters who carried out the measures. The fundamental division in the qualitative assessment of a FT is the conversion between $\mathrm{FT}_{2}$ - and $\mathrm{FT}_{2}+$. At this stage, there is a conversion to the management of light-demanding tree species by group selection. The methods of evenaged silviculture techniques are minimized, and the selection of target trees (or groups of target trees) and control methods of forest management planning play the main role. From a broader, silvicultural point of view, this conversion could be considered to be complete in the FT 2+ forest type. However, according to the definitions of the special function of forests in the buffer zone of the national park, all parameters are fulfilled only in the FT1 type.

Assessments of forest types were based on the mapping of patches (see above). Every patch was assessed and classified during field work in 1992, 2003 and 2013 according to forest type parameters - basal area measurement as the basis for evaluating the tree species composition, spatial structure, key measures used during transformation, and regeneration (Fig. 2). Spatio-temporal data and analyses were performed in the software ArcGIS and MS Excel. 


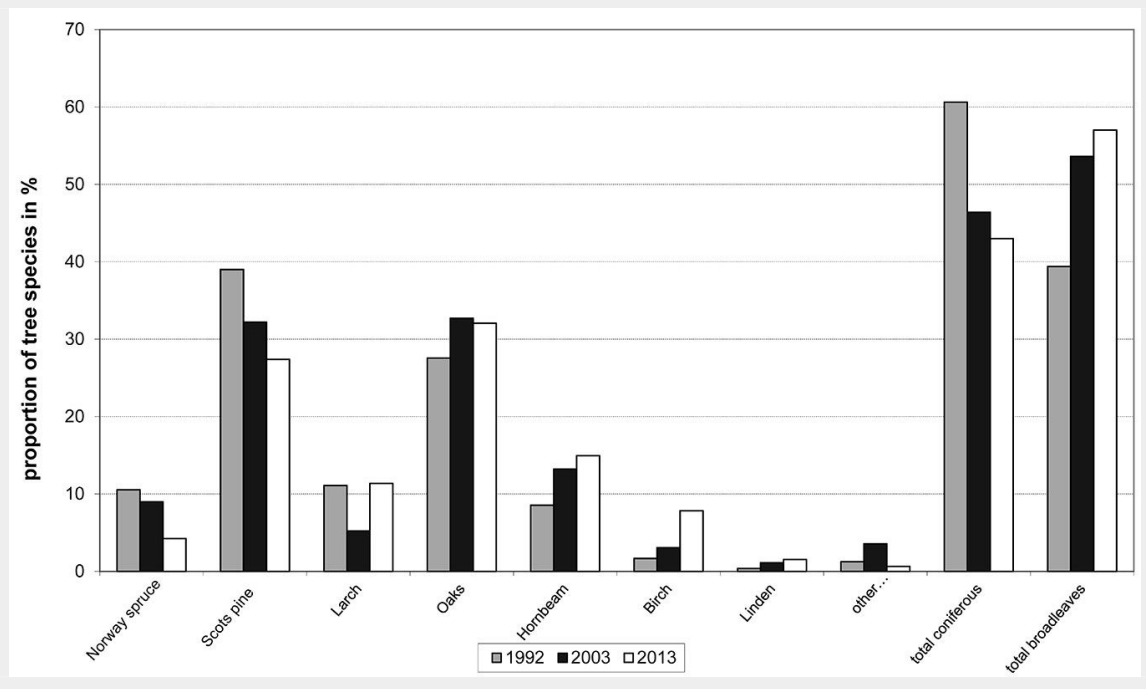

Fig. 3 - Proportion of tree species (in \%) according to basal area $\left(\mathrm{m}^{2}\right)$ in 1992-2013.

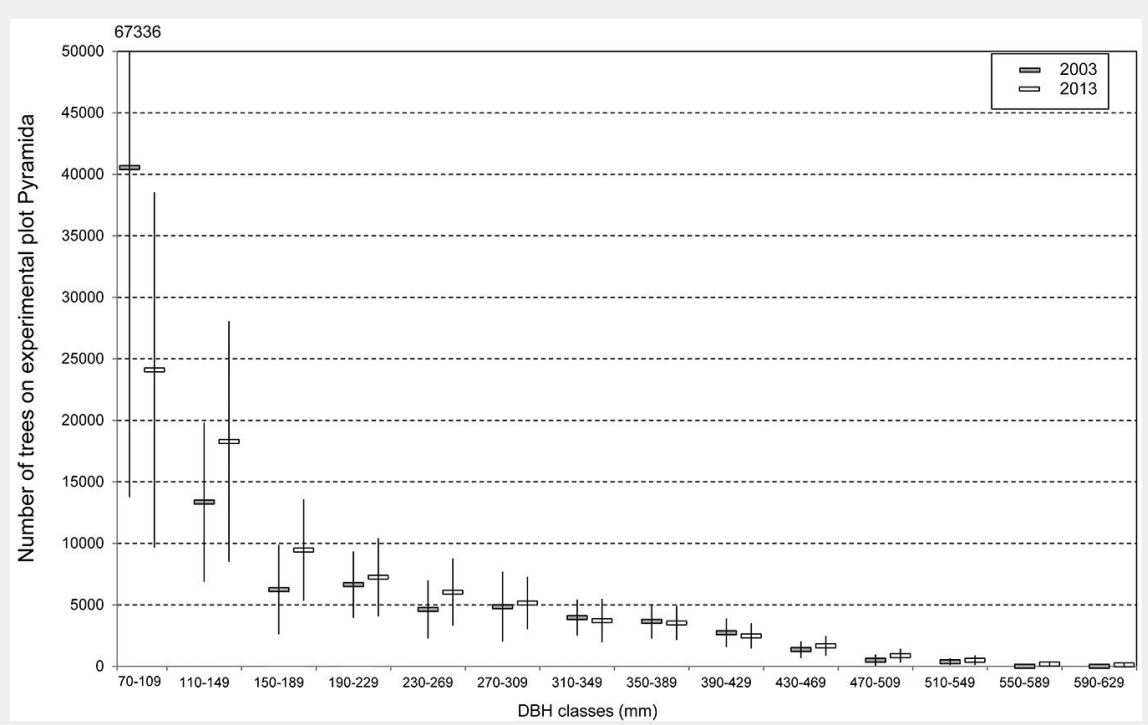

Fig. 4 - Number of trees according to DBH classes. Thin lines show confidence intervals.

A transitional matrix was created for assessing the duration of conversion. Due to the limited range of data (one primary and two repeated surveys) it was not possible to perform a significant model calculation of the expected duration of conversion; therefore, this was derived empirically.

\section{Results}

Changes in tree species composition and $\mathrm{DBH}$ distribution

In the period 1992-2013 there was a marked change from the previous predominance of coniferous species to a predominance of broadleaved species. The proportion of conifers decreased from $61.0 \%$ to $42.0 \%$, and the proportion of broadleaved trees increased reciprocally (Fig. 3). A significant decrease was found for Scots pine, the former main tree species, whose proportion decreased from $39.0 \%$ to $28.0 \%$. Similarly, the proportion of spruce declined from $11.0 \%$ to $4.0 \%$ In both cases, this was the result of the targeted support of admixed broadleaved trees. The decline of Scots pine would be even more pronounced if assessed according to the number of trees. Larger Scots pines in $\mathrm{FT}_{2}$ - and $\mathrm{FT}_{2}+$ reacted to the release caused by the felling of adjacent Scots pines by increased light increment, so the decline in the proportion of Scots pine according to DBH was not so pronounced. An increasing proportion of hornbeam from $8.5 \%$ to $15.0 \%$ reflected its dynamics as a former strictly understorey species that was not considered a target species in previous production systems. The situation for birch (which increased from $1.7 \%$ to $7.8 \%$ ) is similar, with the presence of pioneer trees becoming a significant source of forest biodiversity. The increase of trees in the DBH classes 110-149 mm and 150-189 mm reflected a clear growing response of broadleaved trees (mainly mixed in young Scots pine

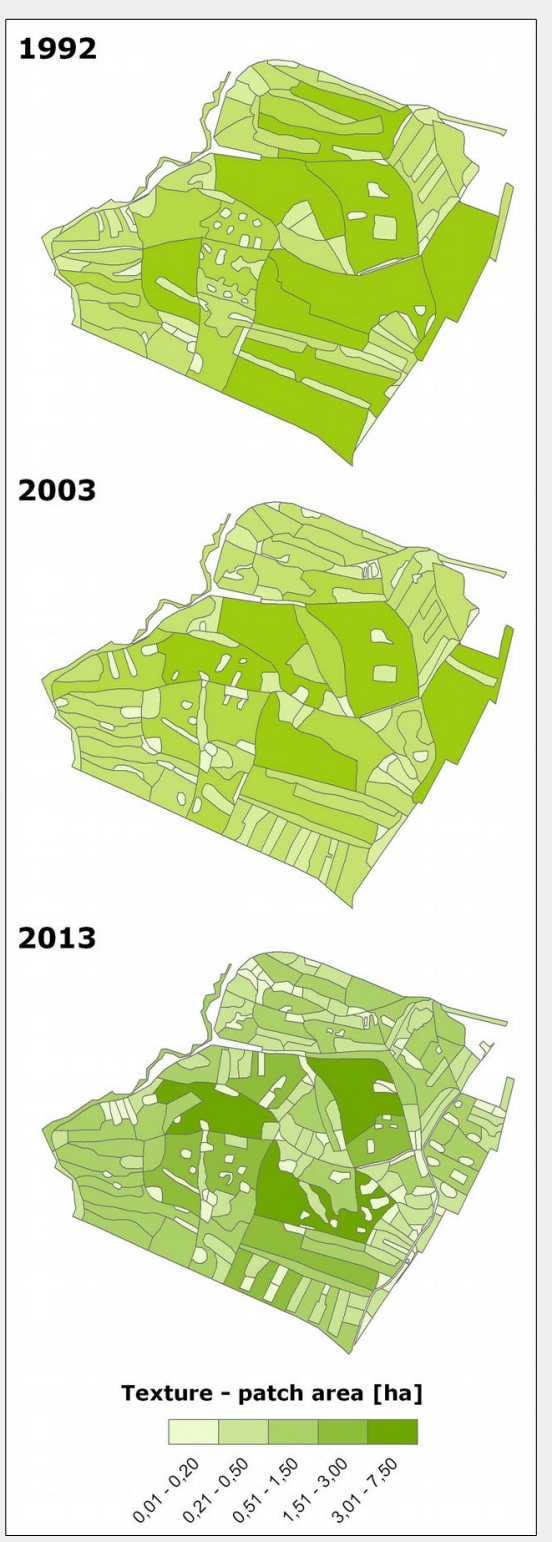

Fig. 5 - Patch dynamics in 1992-2013 according to patch area classification.

small pole stage stands) to the release and their rapid conversion to these DBH classes. This caused a sharp decline in the number of trees in the DBH class $70-109 \mathrm{~mm}$ (Fig. 4). Despite the planting and underplanting of beech in 51 groups on a total area of 7.1 ha from 1992-2013, there has not yet been a recorded increase of beech, since these have not yet grown over the $\mathrm{DBH} \geq 7 \mathrm{~cm}$ threshold. There was also a slow but steady increase in the number of large trees that were left as future habitat trees (in DBH classes $430+\mathrm{mm}$ ).

\section{Patch dynamics (texture changes)}

The gradual fragmentation and creation of heterogeneous spatial structure is demonstrated in Fig. 5, which shows the introduction of regeneration felling into former large uniform stands. These patches are used (i) for introducing missing beech, and (ii) for the release of natural regeneration of introduced broadleaved trees in 
Fig. 6 - Patch structure changes in 1992-2013 according to the number of patches and patch area.
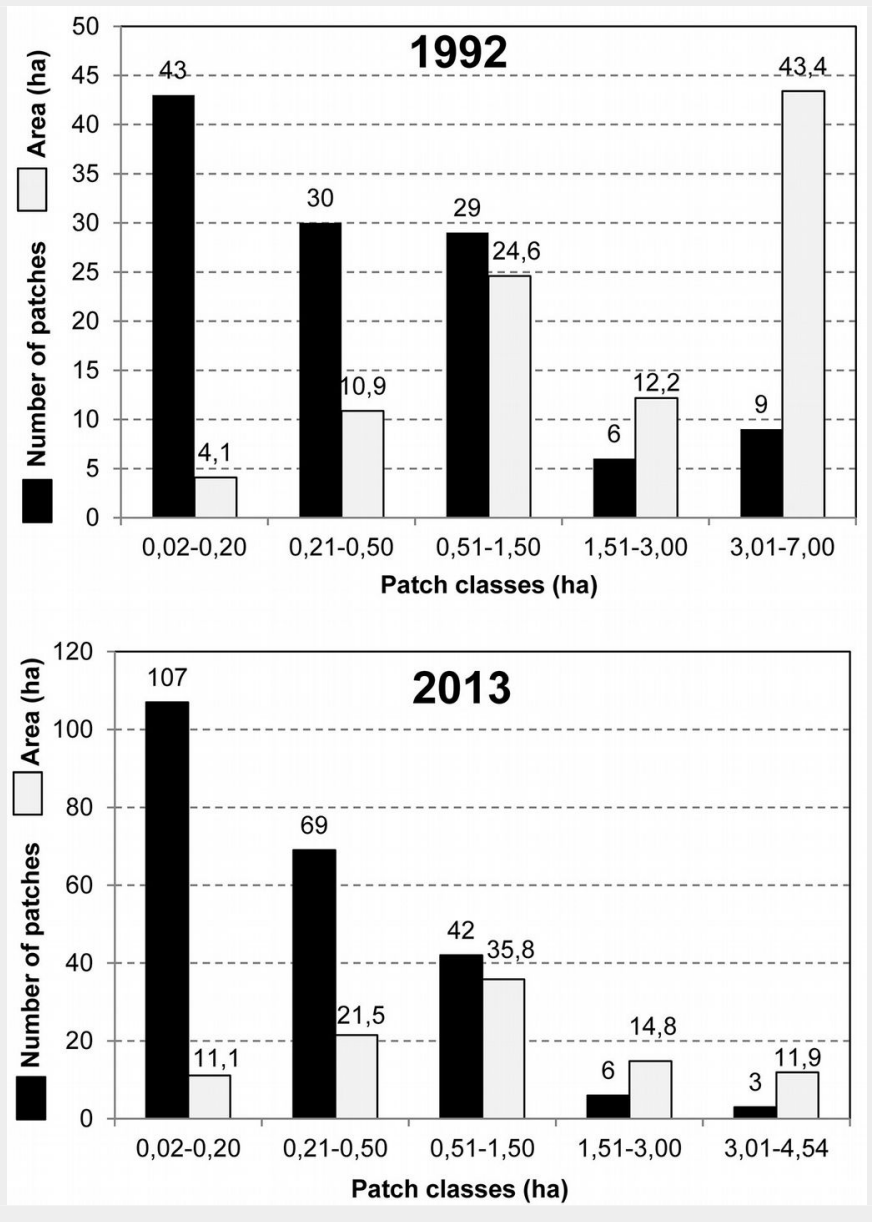

older stands with a prevalence of Scots pine or Norway spruce. This is shown by an analysis of the number and size of patches (Fig. 6). Originally (1992), spatially dominant patches in the class 3.01-7.00 ha covered 43.4 ha ( $46 \%$ of the area). They are currently being replaced by the predominant $0.51-1.50$ ha class, which was "created" by the fragmentation of the largest

Fig. 7 - Box plot analysis of patch areas in 19922013.

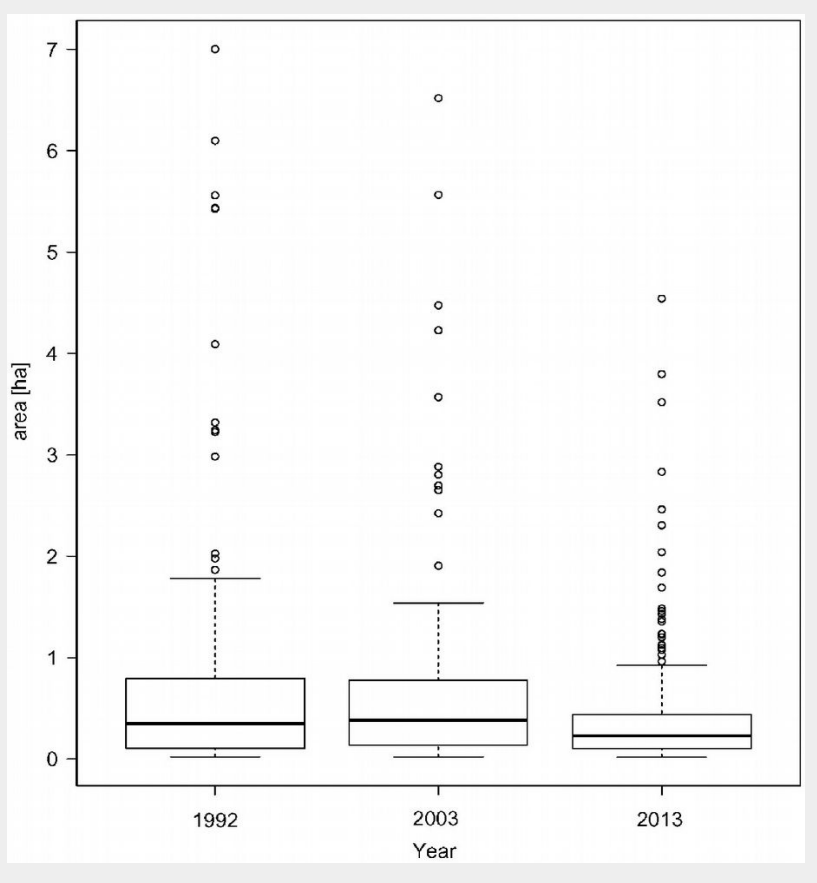

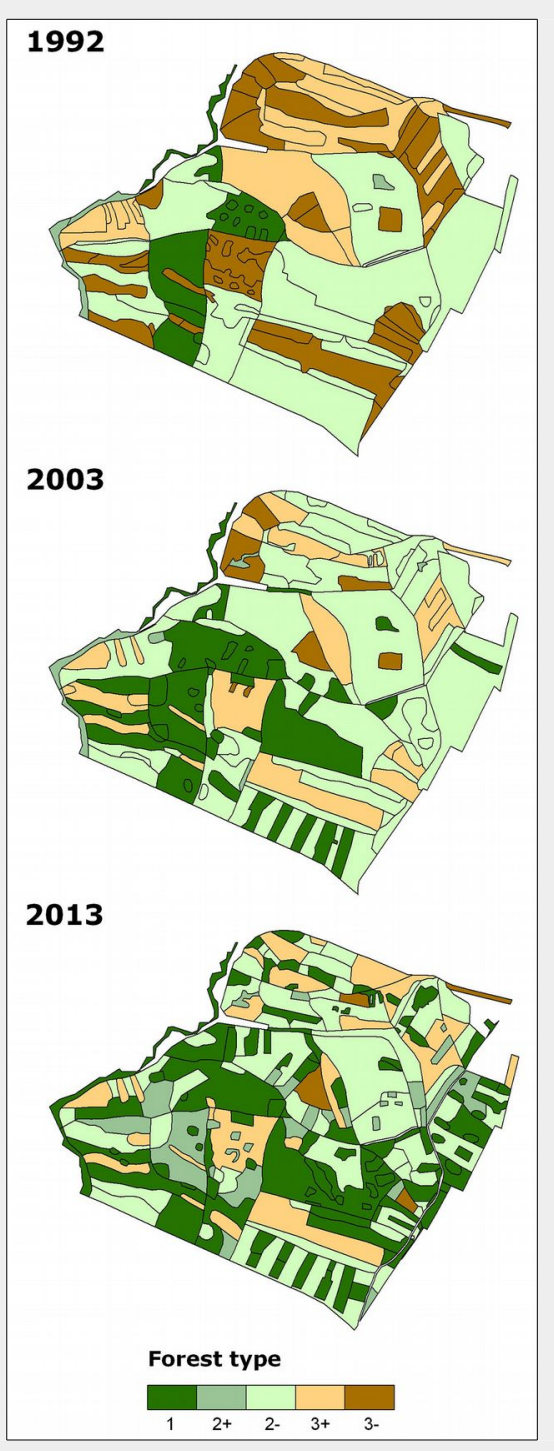

Fig. 8 - Changes in the forest types distribution in 1992-2013.

1.50 ha (i.e., between patches from the $0.51-1.50$ ha class) in 2013. The median value and the interval of values in the range 25$75 \%$ slightly decreased. The average size of one patch decreased from 0.8 ha (1992) to 0.4 ha (2013). The number of patches increased from 117 in 1992 to 227 in 2013 (Fig. 6).

Forest types changes and the duration of conversion

The development of the spatial distribution of forest types in the Pyramida experimental forest is shown in Fig. 8. In the southern part of the experimental forest a faster conversion to the target forest types (FT1, FT2+) can be observed, which was caused by the better condition of the stands in 1992. Selectively performed silvicultural practices not only created a finer spatial structure (see Fig. 6), but the selection of target trees and support for the natural regeneration of autochthonous tree species also shifted individual stands toward the target forest type.

A quantification of changes in the areas 


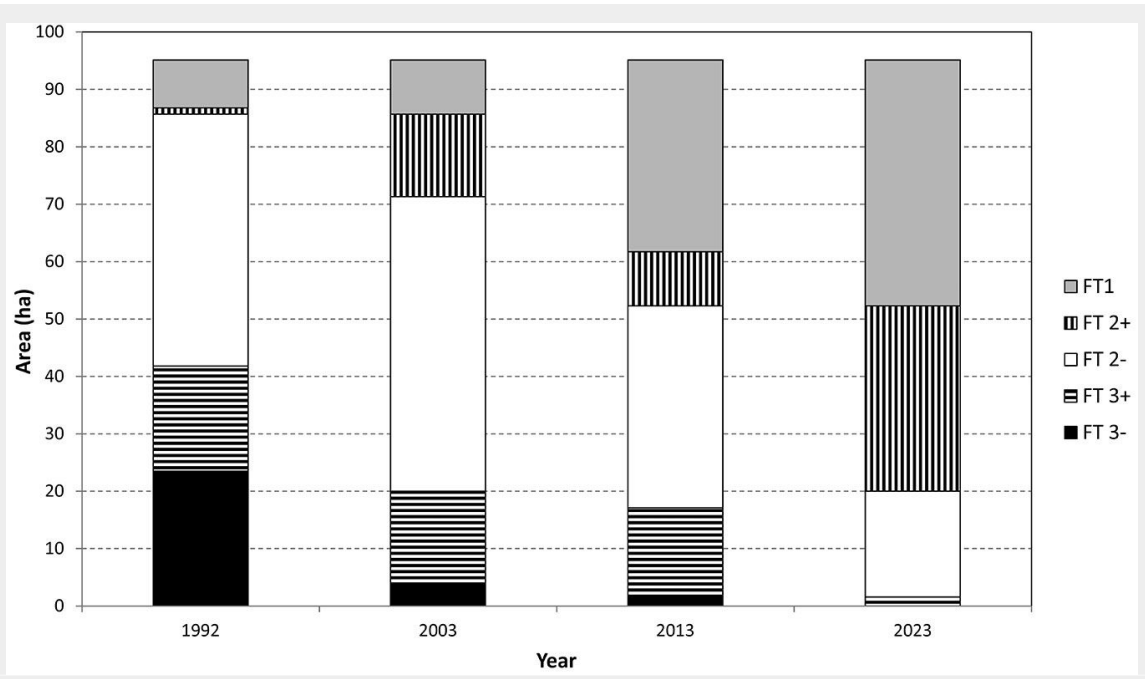

Fig. 9 - Proportion of forest types according to area in 1992-2013 and estimated proportion in 2023.

of forest types (Fig. 9) shows a continuous increase of $\mathrm{FT} 1$, with spatial proportion increasing from $8.7 \%$ to $45.0 \%$ in 2013 . The opposite trend is apparent for pine-dominated forest types (FT3-, $\mathrm{FT}_{3}+$ ), which represented only a minor part of the experimental forest in 2013 (1.7\%). The present balance of the spatial proportion of FT 2and $\mathrm{FT}_{2}+$, which serve as transitional forest types during the conversion, is also evident.

From a broader silvicultural point of view, 33.4 ha (35.1\% of the area) of the Pyramida experimental forest were converted during the last 20 years into $\mathrm{FT}_{1}$ and $\mathrm{FT}_{2}+$. In 30 years since the start of conversion (by 2023) we expect a conversion of 65.7 ha (69.1\% of the area). If we include the $8.3+1.1$ ha area (FT1 and FT2 + in 1992) that did not need to be converted, we can expect a total converted area of 75.1 ha $(79.0 \%$ of the area - Fig. 10).

When considering only the conversion to FT1, 25.1 ha $(26.4 \%)$ of the experimental forest were converted during the last 20 years. In 30 years since the start of conversion (2023), we expect a conversion of 34.5 ha $(36.3 \%$ of the area). If we include the 8.3 ha $(8.7 \%$ of the area) that did not need to be converted, the total area FT1 forest after 30 years of conversion will be 42.8 ha ( $45.0 \%$ of the area - Fig. 10). Regarding the conversion of former young (20-30 years) pine-dominated plantations with a minimal composition of broadleaved tree species, the conversion duration will last at least 5060 years (if we do not use massive underplanting of target tree species).

\section{Discussion}

\section{The duration of conversion}

The duration of conversion always depends on (i) the difference between the initial and target state of the stands and (ii) the selection of silvicultural practices used for achieving the target goal. Among other reasons, such selection depends on the (un)willingness to invest more financial funds into the conversion in the form of introducing missing target species. Considering the conversion of spruce stands (where, e.g., beech and fir are introduced to achieve spatial differentiation), the target goal can be reached in about 50-60 years (Tesař et al. 2004) and the conversion process can be modeled plausibly (Sterba 2002). During this process the even-aged distribution is changed to an uneven-aged distribution by structural thinnings (sensu Schütz 2002b), which are (primarily) focused on the structural diversification of DBH. In the case of changes to the total tree species composition (from ageing Scots pine stand to oak-beech-birch mixture) using selective thinning and successive gap creation, the expected modeled time has been estimated as more than 30 years (Kint et al. 2006). The results from Pyramida confirm this time frame. We expect the conversion of former ageing Scots pine dominated stands by 2023 , because of disseminated old oaks (conversion from $\mathrm{FT}_{3}+$ and in particular FT2- to FT1). However, there are no known models for such young Scots pine dominated stands (from $\mathrm{FT}_{3}$ - to $\mathrm{FT}_{2+}$ ).

\section{The key role of disseminated oaks}

A primary issue is the success of oak natural regeneration from disseminated old oaks. The matrix of old oaks might be very irregular, and not only direct seed rain (and creating new gaps with oak regeneration) but bird dispersal may also need to be used. Mosandl \& Kleinert (1998) found that dispersion by jays resulted in oak being more homogeneously distributed in comparison with Scots pine, while Scots pine was obviously more aggregated than oak, except in young timber stands. Such a distribution may be used for the protection of oak at our site: after oaks become established, it is important to leave the shelter of the old Scots pine stand relatively dense. This promotes oak and limits the Scots pine regeneration (Mosandl \& Kleinert 1998). According to spatial pattern analyses of seedling distribution from disseminated oaks in an ageing Scots pine forest, there is a high potential for seed dispersion - more than $100 \mathrm{~m}$ from an individual or group of trees for both oak and beech (Dobrovolny 2014). Such patterns are confirmed by the number and distances of old disseminated oaks in Pyramida (sensu Mosandl \& Kleinert 1998, Dobrovolny 2014).

Concerning the creation of gaps, one important question is the size of gaps to be achieved. The number of oak seedlings and

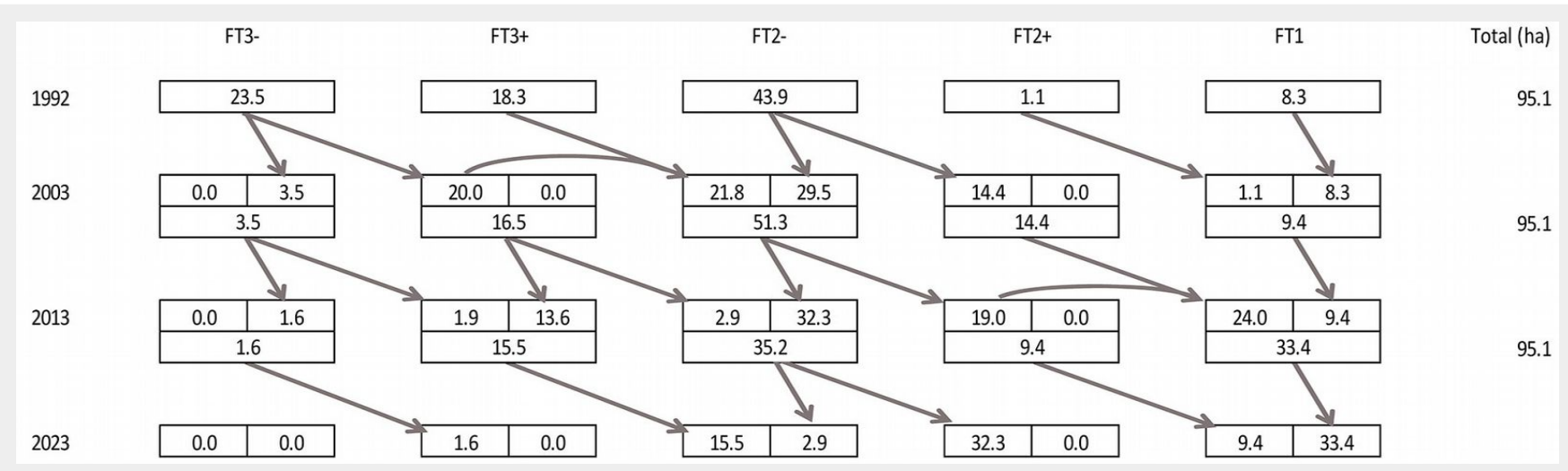

Fig. 10 - Transitional matrix of forest types shifts in 1992-2013 and estimated shift to 2023. 
saplings significantly depended on the gap size (Dobrowolska 2006). The highest frequency of oak seedlings less than $0.1 \mathrm{~m}$ in height was found in gaps of $100-150 \mathrm{~m}^{2}$ and $151-300 \mathrm{~m}^{2}(P<0.01)$. But the number of oak saplings was greatest in the largest gaps (area $>300 \mathrm{~m}^{2}$ ). The amount of oak regeneration within a particular gap depended on the number of oak trees surrounding the gap (Dobrowolska 2006). In the mosaic of newly created gaps in Pyramida, the prevailing gap size is 0.05-0.09 ha, and oak is more successful than the predominant Scots pine in such gaps.

\section{Conversion strategies and promoting old-growth attributes}

Though experience from the conversion of Scots pine-dominated plantations is rather limited, essential changes in species composition and forest management have been documented (Zerbe 2002). Unfortunately, knowledge from mixed stands with spruce, fir and beech are transferable only to some extent. Light-demanding tree species prefer a group distribution of equally high groups due to their requirements for light. Kint et al. (2009) published a 75-year simulation of the conversion Scots pine stands to oak (birch) stands, using three possible strategies: (i) intensified thinning; (ii) random gap creation in combination with thinning; and (iii) directed gap creation in combination with 12 conversion regimes. Only strategy (iii) was able to maintain and increase the modeled birch admixture within the stand. A conversion regime in which conversion is realized by a combination of thinning from above, retention of Scots pine trees at final felling, and cutting cycles of 6 years was recommended as a good compromise between stand productivity and biodiversity (Kint et al. 2009). In practice, a combination of all the three strategies is necessary. Strategy (i) is most commonly used, but intensified thinning in young Scots pine stands could result in lower stand stability. We recommend light thinning with a short cutting cycle. Random gap creation (strategy ii) is very often supplemented by direct gap creation (strategy iii) for the optimization of stand structure, and is normally combined with the protection of habitat trees (e.g., old oaks that are released for seeds and later left to natural death and decomposition). This combination of strategies diversifies the former uniform stand structure. Differently large patches with various jagged edges create the conditions for various groups of organisms, and therefore create a heterogeneous mosaic of micro-habitats suitable for restoring old-growth attributes in regrowth and secondary forests (sensu Bauhus et al. 2009, Göttmark 2007, 2013).

Twenty years of experience with the conversion of forests in the buffer zone of the Podyjí National Park represents 20 years of "thinking in time". The whole process can be considered as forest management designed to maintain old-growth attributes (sensu Bauhus et al. 2009), developing from traditional management practices to non-traditional management combined with species management (sensu Göttmark 2013).

\section{Conclusions}

Conversion of former Scots pine plantations was evaluated after 20 years of conversion. The proportion of conifers decreased from $61.0 \%$ to $42.0 \%$, and the proportion of broadleaved species increased accordingly. The mean size of one patch decreased from 0.8 ha (1992) to 0.4 ha (2013). The spatial proportion of the target forest type (uneven-aged oak-dominated forest) increased from $8.5 \%$ in 1992 to $45.0 \%$ in $2013.35 .1 \%$ of the area was fully converted during the 20 years. We expect $69.1 \%$ of the area to be converted after 30 years (2023) and the increasing proportion of European beech in the same time.

\section{Acknowledgements}

The authors would like to thank Jirí Zahradníček for field work during the inventories in 2003 and 2013. Many thanks to foresters Petr Růžička, Jiř́ Novák, Vladimír Auer, Milan Porízka and Petr Vančura from the Podyjí National Park Administration for their support of our work and for help during our field surveys over the last 20 years. Petra Doleželová helped with technical matters and David Hardekopf carried out the proofreading. This work was supported by an institutional subsidy (VUKOZ-IP-0002 7073).

\section{References}

Anonymous (1992). Lesní hospodárský plán pro lesní hospodárský celek Podyjí. [Forest management plan for Podyjí National Park]. Ústav pro hospodárskou úpravu lesu, Brno, Czech Republic, pp. 333. [in Czech]

Bauhus J, Puettmann K, Messier C (2009). Silviculture for old-growth attributes. Forest Ecology and Management 258: 525-537. - doi: 10.1016/j.foreco.2009.01.053

Biolley HE (1920). L'aménagement des forêts par la méthode expérimentale et spécialement la méthode du contrôle. [Forest management based on experimental methods and on the control method especially]. Attinger, Paris, France, pp. 90. [in French]

Brang $P$, Spathelf $P$, Bo Larsen J, Bauhus J, Bončina A, Chauvin C, Drössler L, García-Güemes C, Heiri C, Kerr G, Lexer MJ, Mason B, Mohren F, Mühlethaler U, Nocentini S, Svoboda M (2014). Suitability of close-to-nature silviculture for adapting temperate European forests to climate change. Forestry 87: 492-503. - doi: 10.1093/ forestry/cpuo18

Carey AB (2003). Biocomplexity and restoration of biodiversity in temperate coniferous forest: inducing spatial heterogeneity with variabledensity thinning. Forestry 76: 127-136. - doi: 10.1093/forestry/76.2.127

Chytry M, Vicherek J (1995). Lesní vegetace Národního parku Podyjí. [Forest vegetation of Podyjí National Park]. Academia, Praha, Czech Republic, pp. 159. [in Czech]
Čižmář Z (2008). Zivot a smrt v mladší dobe kamenné. [Life and death in the early Stone Age]. Ústav archeologické památkové péče, Brno, Czech Republic, pp. 293. [in Czech]

Decocq G, Aubert M, Dupont F, Alard D, Saguez $\mathrm{R}$, Wattez-Fanger A, Foucault B, Delelis-Dusollier A, Bardat J (2004). Plant diversity in a managed temperate deciduous forest: understorey response to two silvicultural systems. Journal of Applied Ecology 41: 1065-1079. - doi: 10.1111/ j.0021-8901.2004.00960.x

Diaci J, Kerr G, OHara K (2011). Twenty-first century forestry: integrating ecologically based, uneven-aged silviculture with increased demands on forests. Forestry 5: 463-465. - doi: 10.1093/forestry/cpro53

Dobrovolny L (2014). Succession of climax tree species within the allochtonous coniferous stands. In: Book of abstracts of the " 9 th IUFRO International Conference on Uneven-Aged Silviculture". WSL, Birmensdorf-Zürich, Switzerland, pp. 40.

Dobrowolska D (2006). Oak natural regeneration and conversion processes in mixed Scots pine stands. Forestry 79: 503-513. - doi: 10.1093/ forestry/cplo34

Engler A (1905). Aus der theorie und praxis des femelschlagbetriebes. [Theory and practice of shelterwood silvicuture]. Schweizerische Zeitschirft for Forstwesen 56: 123-131. [in German] Göttmark F (2007). Careful partial harvesting in conservation stands and retention of large oaks favour oak regeneration. Biological Conservation 140: 349-358. - doi: 10.1016/j.biocon.20 07.08 .018

Göttmark F (2013). Habitat management alternatives for conservation forests in the temperate zone: review, synthesis, and implications. Forest Ecology and Management 306: 292-307. doi: 10.1016/j.foreco.2013.06.014

IUSS Working Group WRB (2014). World reference base for soil resources 2014. International soil classification system for naming soils and creating legends for soil maps. FAO, Rome, Italy, pp. 181.

Johann E (2006). Historical development of nature-based forestry in Central Europe. In: "Nature-based forestry in Central Europe: Iternatives to industrial forestry and strict preservation" (Diaci J ed). University of Ljubljana, Slovenia, pp. 1-17. [online] URL: http://www. anw-niedersachsen.de/Diaci_Nature_based_for estry.pdf\#page $=11$

Kint V, Geudens G, Mohren GMJ, Lust N (2006). Silvicultural interpretation of natural vegetation dynamics in ageing Scots pine stands for their conversion into mixed broadleaved stands. Forest Ecology and Management 223: 363-370. - doi: 10.1016/j.foreco.2005.11.018 Kint V, Lasch P, Lindner M, Muys B (2009). Multipurpose conversion of Scots pine towards mixed oak-birch stands - A long-term simulation approach. Forest Ecology and Management 257: 199-214. - doi: 10.1016/j.foreco.2008.08.031 Kubát J (2002). Klíc ke kvetene Ceské republiky. [Field guide for the flora of the Czech Republic]. Academia, Praha, Czech Republic, pp. 927. [in Czech]

Möller A (1922). Dauerwaldgedanke. [The idea of Dauerwald]. Springer, Berlin, Germany, pp. 84. [in German] 
Mosandl R, Kleinert A (1998). Development of oaks (Quercus petraea (Matt.) Liebl.) emerged from bird-dispersed seeds under old-growth pine (Pinus silvestris L.) stands. Forest Ecology and Management 106: 35-44. - doi: 10.1016/S037 8-1127(97)00237-5

O'Hara K (2014). Multiaged silviculture. Oxford University Press, Oxford, United Kingdom, pp. 213. [online] URL: http://books.google.com/ books?id=CcxLBAAAQBAJ

R Development Core Team (2011). A language and environment for statistical computing. Vienna, Austria. [online] URL: http://www.Rproject.org/

Reiterová L, Škorpík M (2012). Plán péče o Národní park Podyjí a jeho ochranné pásmo. [Management plan for Podyjí National Park and its protective zone]. Správa Národního parku Podyjí, Znojmo, Czech republic, pp. 316. [in Czech]

Schütz JP (1999). Close-to-nature silviculture: is this concept compatible with species diversity? Forestry 72: 359-366. - doi: 10.1093/forestry/72. 4.359

Schütz JP (2001). Der Plenterwald und weitere Formen strukturierten und gemischter Wälder. [The selection forest and other forms of structured and mixed forests]. Parey, Singhofen,
Germany, pp. 207. [in German]

Schütz JP (2002a). Silvicultural tools to develop irregular and diverse forest structures. Forestry 75: 329-337. - doi: 10.1093/forestry/75.4.329 Schütz JP (2002b). Die Plenterung und ihre unterschiedlichen Formen. [The selection principle and its diverse forms]. ETH Zentrum, Zürich, Switzerland, pp. 127. [in German]

Seymour RS, Hunter ML (1999). Principles of ecological forestry. In: "Maintaining Biodiversity in Forest Ecosystems" (Hunter ML eds). Cambridge University Press, Cambridge, UK, pp. 22-61. [online] URL: http://nnrg.org/wp-con tent/uploads/2015/03/seymourchapter.pdf

Škorpík M (1993). Plán péče o Národní park Podyjí a jeho ochranné pásmo. [Management plan for Podyjí National Park and its protective zone]. Správa Národního parku Podyjí, Znojmo, Czech Republic, pp. 167. [in Czech]

Sterba H (2002). Forest inventories and growth models to examine management strategies for forest in transition. Forestry 75: 411-418. - doi: 10.1093/forestry/75.4.411

Tesař V, Klimo E, Kraus M, Souček J (2004). Dlouhodobá prestavba jehličnatého lesa na Hetlíne - Kutnohorské hospodárství. [Longterm conversion of coniferous stands in Hetlín, Kutná hora municipality]. Mendel University
Press, Brno, Czech Republic, pp. 6o. [in Czech] Tolasz R (2007). Atlas podnebí Ceska. [Climate Atlas of the Czech Republic]. Czech Hydrometeorological Institute, Praha, Czech Republic, pp. 255. [in Czech]

Vrška T (1998). Historický vývoj lesu na území NP Podyjí a v bližším okolí do roku 1948. [The history of forests in Podyji National Park and its surrounding]. Thayensia 1: 101-124. [in Czech] Zerbe S (2002). Restoration of natural broadleaved woodland in Central Europe on sites with coniferous forest plantations. Forest Ecology and Management 167: 27-42. - doi: 10.1016/ S0378-1127(01)00686-7

\section{Supplementary Material}

Tab. S1 - Measured parameters from statistical inventories at the Pyramida study site.

Tab. S2 - Parameters of concentric circles on the inventory plots.

Tab. S3 - Measured objects and attributes on the inventory plots.

Link:Vrska_1967@supplo01.pdf 